\title{
Strategies to optimize kidney recovery and preservation in transplantation: specific aspects in pediatric transplantation
}

\author{
Tackwa Khalifeh • Edouard Baulier • Sylvain Le Pape • \\ Thomas Kerforne • Remy Coudroy • Souleymane Maiga • \\ Thierry Hauet • Michel Pinsard • Frederic Favreau
}

Received: 27 February 2014 / Revised: 9 July 2014 / Accepted: 21 July 2014 / Published online: 4 September 2014

(C) IPNA 2014

\begin{abstract}
In renal transplantation, live donor kidney grafts are associated with optimum success rates due to the shorter period of ischemia during the surgical procedure. The current shortage of donor organs for adult patients has caused a shift towards deceased donors, often with co-morbidity factors, whose organs are more sensitive to ischemia-reperfusion injury, which is unavoidable during transplantation. Donor management is pivotal to kidney graft survival through the control of the ischemiareperfusion sequence, which is known to stimulate numerous deleterious or regenerative pathways. Although the key role of endothelial cells has been established, the complexity of the injury, associated with stimulation of different cell signaling pathways, such as unfolded protein response and cell death, prevents the definition of a unique therapeutic target. Preclinical transplant models in large animals are necessary to establish relationships and kinetics and have already contributed to the improvement of organ preservation. Therapeutic strategies using mesenchymal stem cells to induce allograft tolerance are
\end{abstract}

T. Khalifeh $\cdot$ E. Baulier $\cdot$ S. Le Pape $\cdot$ T. Kerforne $\cdot$ R. Coudroy $\cdot$

S. Maiga $\cdot$ T. Hauet $\cdot$ M. Pinsard $\cdot$ F. Favreau

Ischémie-Reperfusion en Transplantation Rénale, INSERM, U1082,

Poitiers 86000, France

E. Baulier $\cdot$ S. Le Pape $\cdot$ T. Kerforne $\cdot$ R. Coudroy $\cdot$ S. Maiga

T. Hauet $\cdot$ F. Favreau

Faculté de Médecine et de Pharmacie, Université de Poitiers,

Poitiers 86000, France

T. Khalifeh

Service Médico-Chirurgical de Pédiatrie, CHU de Poitiers,

Poitiers 86000, France

E. Baulier $\cdot$ T. Hauet $\cdot$ F. Favreau

Laboratoire de Biochimie, CHU de Poitiers, Poitiers 86000, France

T. Kerforne $\cdot$ M. Pinsard

Service de Réanimation Chirurgicale, CHU de Poitiers,

Poitiers 86000, France promising advances in the treatment of the pediatric recipient in terms of reducing/withdrawing immunosuppressive therapy. In this review we focus on the different donor management strategies in kidney graft conditioning and on graft preservation consequences by highlighting the role of endothelial cells. We also propose strategies for preventing ischemia-reperfusion, such as cell therapy.

Keywords Ischemia-reperfusion · Graft preservation . Endothelial cell injuries · Organ management $\cdot$ Kidney graft recovery $\cdot$ Stem cell therapy

\section{Introduction}

The incidence of end-stage renal disease in Europe is estimated at between 75 to 120 per million population per year in adults and is less frequent in children, with an incidence of 6

R. Coudroy

Service de Réanimation Médicale, CHU de Poitiers, Poitiers 86000 , France

S. Maiga

Service de Radiologie, CHU de Poitiers, Poitiers 86000, France

T. Hauet

Fédération Hospitalo-Universitaire, SUPORT, Limoges, Poitiers and Tours, CHU La Milétrie, Poitiers 86000, France

M. Pinsard

Organ Procurement Unit, CHU de Poitiers, Poitiers 86000, France

T. Hauet $(\bowtie)$

Inserm U1082, 2 rue de la Miletrie, BP577, 86021 Poitiers Cedex,

France

e-mail: thierry.hauet@gmail.com 
10 per million general population. Congenital anomalies of the kidney and urinary tract represent nearly half of end-stage renal disease (ESRD) patients and remain the major pediatric etiology, followed by glomerular and hereditary diseases [1]. Replacement therapies depend on child age and the country concerned. Peritoneal dialysis (PD) is the preferred therapy in children between 0 and 14 years old in Europe and the USA, and almost half of the patients starting renal replacement therapy are on PD. However, in developed countries, 15-20\% of the pediatric patients with ESRD receive a kidney transplant as first-line therapy $[2,3]$. This surgical therapy should be the preferred treatment and strongly encouraged as it greatly diminishes the risk of death by reducing cardiovascular comorbidities, mainly in children aged $<2$ years, and greatly increases the patient's quality of life [4].

At the present time, the number of patients waiting for transplants is increasing each year while the number of transplants performed every year remains stable. However, in France, pediatric kidney transplant is the most frequently used replacement therapy (between 60 and $80 \%$ ) due to the national pediatric priority promoting a very short waiting period (median 3.5 months), with about $20 \%$ of transplants being preemptive [5]. In contrast to adult recipients, in pediatric patients, the majority of transplanted organs come from living donors (LD) [6]. In both LD and donation after brain death (DBD) situations, a short period of ischemia during surgical procedure and organ preservation is associated with the optimization of graft quality. The kidney graft shortage has induced an evolution in donor demography such that in adults, donor selection criteria have been expanded to allow donation after cardiac death (DCD), even though such organs are more sensitive to ischemic lesions due to hemodynamic instability and co-morbidity factors found in DBD, such as dyslipidemia, high blood pressure or old donors aged $>65$ years (expanded criteria donors; ECD). Due to the priority of pediatric patients, such grafts are not currently transplanted to children with ESRD who mostly benefit from young donors. However, some children on the transplant waiting list, including sensitized children, still remain on dialysis for several years, thus reducing their life expectancy and increasing the risk of cardiovascular comorbidities [4].

Every transplanted organ is necessarily exposed to an ischemia-reperfusion sequence. Ischemia begins with organ collection and continues to the end of ex vivo graft preservation. At the time of transplantation, reperfusion follows ischemia, once the graft is connected to the vascular system of the recipient. The absence of blood perfusion induces damage that may be irreversible and possibly dramatically affect graft outcome after transplantation. Depending on the type of donor, $\mathrm{LD}, \mathrm{DBD}$ or DCD, each condition is characterized by a difference in graft sensitivity to ischemia-reperfusion consequences. The limited period of cold preservation in $\mathrm{LD}$, the longer cold preservation period in DBD and the combination of warm ischemia and cold preservation in DCD induce different severities of renal damage. Reperfusion is known to exacerbate cellular injuries induced by ischemia.

In the first section of this review, we describe the different types of animal models that are essential for the development of innovative and efficient therapies in kidney transplantation. We focus on the different types of donor management for kidney graft conditioning and graft preservation, highlighting the role of endothelial cells, and conclude this review by proposing potential approaches against ischemia-reperfusion, such as pharmacological, biological or cellular therapies.

\section{Animal models relevant to the study of kidney graft recovery and preservation}

Even when large animal studies are essential before moving to clinical trials, it is important to look for ways to reduce the number of experimental animals used [7]. In organ transplantation research, the use of cellular models is limited due to the complexity and the high number of processes involved at the organ level. For example, the unavoidable immunological response in allo-transplantation is closely linked to the numerous pathophysiological pathways induced by ischemia-reperfusion [8], and a cellular model cannot reproduce the interconnections between these different pathways. Thus, experiments with animal models are crucial in studies with the aim of investigating graft preservation and recovery. However, the relevance of data obtained by performing kidney transplantation on animals is limited by inter-species differences and sensitivities found in animal models. In rodents, renal transplant surgery requires experienced surgeons and is associated with numerous surgical failures. Thus, in terms of organ size, large mammal studies are preferred in organ transplantation studies due in part to analogous surgical procedures with humans [9]. The pig in particular is a suitable animal model for renal ischemia-reperfusion studies due to the multipapillary architecture of the kidney, which is similar to that in humans and different from the unipapillary structure of rodents [9-11]. Thus, the arterial and venous network in each species varies notably, having evolved to optimize $\mathrm{O}_{2}$ delivery based on each anatomical configuration, and is especially relevant in ischemia-reperfusion injury studies [10]. The pig is also suitable as a model animal for immunology studies, as previously reported, as well as in various experimental approaches in physiology, pharmacology and surgery [12]. Our laboratory has developed a pig model of renal autotransplantation to study the consequences of renal ischemiareperfusion on long-term graft survival and their modulations. Since piglets are 3 months old at the time of transplantation and have an organ size similar to that in humans, the results are easily extrapolated to the clinical situation in renal 
pediatric transplantation. Thus, this model has allowed us to define new preservation solutions, such as SCOT15, which contains polyethylene glycol (PEG) to limit ischemic injuries [13]. We have also modified our porcine model to better investigate renal graft regeneration in different clinical situations: static cold storage, ischemia at body temperature or poor quality graft from donors with poor hemodynamics [9, 14]. Recently, we used a kidney transplant model to investigate the beneficial effect of injecting stem cells from the amniotic fluid into the recipient. This model allowed us to assess the safety of this therapy and investigate the stimulation of the regenerative processes by stem cells [15].

\section{Pediatric organ donors and their management}

Due to the lack of specific studies on the pediatric donor population, the principal pediatric donor management guidelines are mostly based on data collected in adult studies.

LD kidney transplantation accounted for about $40 \%$ of the kidney grafts in the North American Pediatric register in 2009 [3]. Living kidney donation confers higher graft survival to the recipient compared to a deceased kidney donation, with conditional half-life of 12 years for the latter and 15 years for LD [16]. LD reduces the additional morbidity and mortality factors associated with the waiting time for a DBD organ [17]. Parents represent $80 \%$ of LD [18]. The minimum legal age for living donation varies by jurisdiction, ranging from no minimum age limit (in England, Wales and North Ireland) to age 19 years in some Canadian provinces, with underaged living donation even forbidden in some European countries, including France [19]. Donor age is decreasing in the USA according to the "Share 35" program [16]. Minors account for about $20 \%$ of organ donors, and in 2010 less than $10 \%$ of kidney DBD were aged $\leq 10$ years.

In Canada, DBD ranges from 28 to $31 \%$ of children and from 2 to $3 \%$ of neonates who die in pediatric intensive care units. However, only $55 \%$ of DBD children become organ donors [20]. Guidelines for the diagnosis of brain death in children have been recently updated. After confounding factors (e.g. hypotension, hypothermia, metabolic disturbances, drugs that can interfere with neurological examination) have been eliminated, the North American 2011 Guidelines recommend a clinical evaluation by two different physicians, with a focus on the absence of brainstem reflexes, a flaccid tone and apnea testing in a comatose child from 37 weeks gestational age to 18 years old. If these criteria are met, the results of the clinical examination must remain unchanged during a 24-h period for newborns of 37 weeks gestation age to 30 days, and during a 12-h period for children aged from 30 days to 18 years. Cerebral blood flow or electroencephalography are not required but can be used if the clinical examination cannot be completed, if there is any doubt about the results of the examination, or if medication can interfere with clinical evaluation, or in a reduced observational period [21].

DBD management includes the treatment of hypertension during the Cushing phenomenon, followed by cardiovascular support with treatment of hypotension [22], and maintenance of adequate intravascular volume (as sustained hypotension is observed in $53 \%$ of brain dead children) [23], avoiding hydroxyethyl starch [24]. In 2009, Schnuelle et al. suggested that hemodynamic support by dopamine could improve kidney graft function [25]. Hormone replacement with methylprednisolone, vasopressin (as diabetes insipidus is observed in $78 \%$ of DBD children) [23] and thyroid hormone (to reduce vasopressor requirement) [25] is a widely used therapy, but controversial in the USA $[22,26]$. Several studies were unable to find any major effects of donor management on graft quality. However, the use of steroids, diuretics and desmopressin has been associated with an increase in organ survival [26].

Based on the U.S. OPTN/SRTR (U.S. Organ Procurement and Transplantation Network/U.S. Scientific Registry of Transplant Recipients) 2012 annual data, kidney transplantation from DCD donors increased in 2011 [16], but represents less than $10 \%$ of all transplanted pediatric kidneys [27, 28]. A higher number of kidneys obtained by DCD are discarded compared to DBD, although neither an increase in delayed graft function nor graft loss has been observed in DCD [27]. For pediatric DCD kidney transplantation, the American Academy of Pediatrics recommends a period of 2-5 min before certification of death following the withdrawal of life support and the development of cardio-circulatory arrest, apnea and unresponsiveness [29]. The other main difference between adult and pediatric kidney transplants is the longer preservation period of grafts destined for adult recipients. Among the cold-stored kidney transplants over the last 25 years, the median cold ischemia time is $18.7 \mathrm{~h}$ (maximum $64.5 \mathrm{~h}$ ). In comparison, the cold ischemia time is $<24 \mathrm{~h}$ in $73 \%$ of the kidneys transplanted in children in North America [3]. Only $20 \%$ of transplanted kidneys from deceased donors were preserved by machine perfusion in North America in 2009. Between 1996 and 2010, the 1-year graft survival was > $90 \%$ for all deceased donor kidney transplants - except for those stored with machine perfusion for $>24 \mathrm{~h}(83 \%)$ [3]. Post-transplant complications, such as incidence of acute tubular necrosis, are also dependent on the preservation solutions used: $21 \%$ for EuroCollins solution versus $16 \%$ for Wisconsin solution. EuroCollins solution should no longer be used due to the amount of glucose it contains, which can cause deep metabolic acidosis in cold-stored tissue. From a shortterm point-of-view, the use of improved preservation solutions (reviewed in [30]) could be an achievable goal in clinics. Briefly, static storage preservation solutions differ by their electrolyte composition (intracellular, intermediate or extracellular), the impermeant used (lactobionate or raffinose) and 
the colloid (hydroxyethyl starch or PEG) (Table 1) [30]. Notably, the use of preservation solutions containing PEG prevents formation of the immunological synapse and thus reduces the detrimental post-reperfusion immune events, leading to improved graft outcome [13, 31]. SCOT15, which belongs to these fourth-generation solutions, combines an extracellular-like composition with a $20-\mathrm{kDa}$ PEG and is known for its cell-protection capacity and immunocamouflage properties $[13,31,32]$. Although insufficient data are currently available to provide guidelines on preservation solutions for pediatric kidney transplantation, numerous preclinical studies have shown the potential of modifying preservation solutions to improve graft survival [33-35].

In conclusion, the use of adapted preservation solutions in association with the development of therapeutics targeting the emerging signaling pathways is a strategy associated with a strong potential for the improvement of graft outcome and patient quality of life.

\section{Strategies to limit renal ischemia-reperfusion injuries and optimize organ preservation}

Ischemia combines both oxygen and nutrient deprivation, resulting in a perturbation of cellular homeostasis. At the cellular level, the mitochondria and the endoplasmic reticulum are the principal organelles affected [36], with the result that cells are constrained in adapting their biochemical programs. Indeed, ischemia triggers a switch in energy production by activating glycolysis in anaerobic conditions, leading to a sudden fall in ATP concentration due to a lower yield of ATP production compared to oxidative phosphorylation. In this context, shorter durations of transplant preservation in LD conditions could be associated to higher remnant ATP production, thereby explaining the reduced renal parenchymal destruction. In addition, ischemia-induced anaerobic glycolysis alters the cellular redox state and ionic homeostasis [37], modulates the synthesis of lipids and proteins, due in part to an endoplasmic reticulum-induced stress which activates the unfolded protein response [38], and ultimately induces a partial translational arrest [39]. Inseparable from ischemia, the reintroduction of oxygen during the reperfusion is deleterious because of the significant production of reactive oxygen species which are highly toxic to the renal parenchyma [40]. Several pathophysiological processes are associated with oxidative stress, such as inflammation with activation of the complement pathway, coagulation disorders and adhesion of neutrophils and monocytes to the endothelium in association with cytokine and chemokine production [41-43]. In this regard, antioxidants are known to mitigate ischemia-reperfusion injury $[44,45]$. To limit the non-selective target of antioxidant therapy and to avoid the high dose of antioxidants necessary to achieve effective local concentrations, a research team has recently demonstrated that complexation of the membrane-permeable superoxide dismutase mimetic 4hydroxy-Tempo (Tempol) to folate specifically targeted the renal proximal tubules, due to their expression of high levels of folate receptors, - and limited ischemia-reperfusion injury [46]. The preservation period represents a critical therapeutic time window. As current preservation solutions are not yet optimal and can certainly be improved, the use of additiveswhich are mainly pharmacologic agents targeting various cellular processes - is an interesting and easy-to-implement strategy which could improve transplant recovery. We have

Table 1 Characteristics of the main preservation solutions in kidney transplantation ${ }^{\mathrm{a}}$

\begin{tabular}{|c|c|c|c|c|c|c|c|}
\hline \multirow{2}{*}{$\begin{array}{l}\text { Solution type } \\
\begin{array}{l}\text { Name of } \\
\text { preservation } \\
\text { solution }\end{array}\end{array}$} & \multirow{2}{*}{$\begin{array}{l}\text { Intracellular solution: } \\
62 \mathrm{mM}<\left[\mathrm{K}^{+}\right] \\
\text {Belzer } \mathrm{UW}^{\circledR} \text { (Viaspan) }\end{array}$} & \multicolumn{5}{|c|}{ Intermediate solution: $7 \mathrm{mM}<\left[\mathrm{K}^{+}\right]<62 \mathrm{mM}$} & \multirow{2}{*}{$\begin{array}{l}\text { Extracellular solution: } \\
{\left[\mathrm{K}^{+}\right]<7 \mathrm{mM}} \\
\text { SCOT } 15^{\circledR}\end{array}$} \\
\hline & & IGL-1 ${ }^{\circledR}$ & $\mathrm{KPS}^{\circledR}$ & Celsior ${ }^{\circledR}$ & Polysol $^{\circledR}$ & $\begin{array}{l}\text { Custodiol }^{\circledR} \\
\text { HTK }\end{array}$ & \\
\hline $\mathrm{K}^{+}(\mathrm{mM})$ & 125 & 30 & 25 & 15 & 15 & 10 & 5 \\
\hline Buffer & Phosphate & Phosphate & $\begin{array}{r}\text { Phosphate } \\
\text { HEPES }\end{array}$ & Histidine & $\begin{array}{l}\text { Phosphate } \\
\text { HEPES } \\
\text { Histidine }\end{array}$ & Histidine & Carbonate $^{-}$ \\
\hline $\mathrm{pH}$ & 7.3 & 7.3 & 7.4 & 7.3 & 7.4 & 7.2 & 7.3 \\
\hline Impermeant & $\begin{array}{l}\text { Lactobionate } \\
\text { Raffinose }\end{array}$ & $\begin{array}{l}\text { Lactobionate } \\
\text { Raffinose }\end{array}$ & $\begin{array}{l}\text { Glucose } \\
\text { Ribose } \\
\text { Mannitol }\end{array}$ & $\begin{array}{l}\text { Lactobionate } \\
\text { Mannitol }\end{array}$ & $\begin{array}{l}\text { Raffinose } \\
\text { Trehalose } \\
\text { Gluconate }\end{array}$ & Mannitol & Glucose \\
\hline Antioxidant & $\begin{array}{l}\text { Glutathione } \\
\text { Allopurinol }\end{array}$ & $\begin{array}{l}\text { Glutathione } \\
\text { Allopurinol }\end{array}$ & Glutathione & Glutathione & $\begin{array}{l}\text { Glutathione } \\
\alpha \text {-Tocopherol } \\
\text { Ascorbic acid }\end{array}$ & - & - \\
\hline Colloid (g/L) & $\operatorname{HES}(50 \mathrm{~g} / \mathrm{L})$ & $\begin{array}{c}\text { PEG } 35 \mathrm{kDa} \\
(1 \mathrm{~g} / \mathrm{L})\end{array}$ & $\begin{array}{l}\text { HES } \\
\qquad(50 \mathrm{~g} / \mathrm{L})\end{array}$ & - & $\begin{array}{c}\text { PEG } 35 \mathrm{kDa} \\
(20 \mathrm{~g} / \mathrm{L})\end{array}$ & - & PEG $20 \mathrm{kDa}(15 \mathrm{~g} / \mathrm{L})$ \\
\hline
\end{tabular}

HEPES, 4-(2-Hydroxyethyl)-1-piperazine ethanesulfonic acid; HES, hydroxyethyl starch; PEG, polyethylene glycol; UW, University of Wisconsin

${ }^{\text {a }}$ Adapted from Bon et al. [30], with permission 
found that inhibition of the pro-inflammatory P38 MAPK [35] or the addition of trimetazidine, a molecule mainly used in patients with angina pectoris, which has pleiotropic effects, including the inhibition of $\beta$-oxidation of fatty acids - during the preservation period improved renal function after transplantation [47]. The addition of Vectisol ${ }^{\circledR}$, a molecular complex in which a washable vector composed of a cyclic polysaccharide is associated with the strong antioxidant resveratrol (a polyphenol present in red wine) - to the preservation solution has also been shown to be beneficial for renal function recovery [48]. Early organ recovery is commonly used as the main criterion to assess the benefits of strategies mitigating ischemia-reperfusion injury, and its use is justified by the clinical observation that the most obvious consequences of renal ischemia-reperfusion are kidney graft primary nonfunction and delayed graft function [49]. However, the longterm impact of ischemia-reperfusion injury is not to be underestimated as early lesions generated by ischemia-reperfusion induce the death of endothelial cells and tubular epithelial cells, resulting in nephronic mass reduction and inadequate tissue oxygenation and, ultimately, chronic renal failure.

Renal microcirculation is the first target of ischemia-reperfusion injury due to its high sensitivity to hypoxia and its proximity to the blood flow. Ischemia-reperfusion injury causes the phenotype of the vascular endothelial cells to switch from an anti-inflammatory/coagulant to a pro-inflammatory/coagulant [50] phenotype, combining self-antigen presentation [51], innate immune system activation [52], endothelial cell swelling, altered cell-cell contact and altered endothelial cell-basement membrane attachment [53-55]. These phenomena are associated with the no-reflow phenomenon characterized by an increase in the impedance of the microvascular blood flow after re-opening of occluded/ thrombosed vessels $[56,57]$. Hence, preserving the integrity of the structure and functions of endothelial cells during ischemia-reperfusion is critical to improved graft outcome. A variety of techniques are currently available to investigate this crucial cell layer of the renal microvasculature, different techniques, such as vascular filling, light microscopy, microangiography, scanning electron microscopy [58-60] and highresolution micro-computed tomography. The development of novel instruments allowing in vivo analysis of the kidney graft microvasculature in clinical practice is of paramount importance [61] for the early diagnosis of injury and therapeutic monitoring.

A clear understanding of ischemia-reperfusion injury pathophysiology by investigating the relationship between known and emerging signaling pathways is crucial. Among these pathways, autophagy (a process in which cells recycle their components to survive during starvation) and mitophagy [62] and the mitochondrial and endoplasmic reticulum unfolded protein response $[63,64]$ (triggered in response to an accumulation of misfolded proteins in order to regulate protein homeostasis) could offer potential new therapeutic targets to mitigate ischemia-reperfusion injury (Table 2) [65-71]. Moreover, the uncontrolled unfolded protein response is pathological during ischemia, as has been observed in our in vitro models of ischemia-reperfusion. We have also found that the unfolded protein response has specific kinetics during ischemia, with an association between its profile of activation and the level of injury. During the first $6 \mathrm{~h}$ of ischemia, we observed that the administration of unfolded protein response modulators improved cell survival. In the case of pediatric recipients receiving organs with a shorter preservation period than adult recipients, therapeutic strategies targeting the unfolded protein response could be very effective. However, the complexity of the process suggests that activation or inhibition of these pathways in the entire kidney parenchyma could lead to either cell death or cell survival, thereby strengthening the need for an in depth understanding of the kinetics, relationships and mechanisms of these pathways at the organ level to identify safe therapeutic targets.

Another critical issue during organ preservation and the early phase of reperfusion is the activation of coagulation. The sterile inflammation induced by ischemia-reperfusion is linked to coagulation through the activation of tissue factor, thrombin production, fibrin deposition and the activation of the protease-activated receptors [72]. Using our pediatric porcine preclinical model of kidney transplantation, we observed that a direct inhibitor of thrombin prevented delayed graft function [73]. Due to their close contact with blood flow, endothelial cells are an easy-to-reach therapeutic target during organ preservation. Different possibilities for controlling ischemia-reperfusion injury and the rate of delayed graft function by targeting immune components, coagulation effectors or genes involved in cell survival are currently being tested in clinical trials on adult kidney transplantation (summarized in Table 3) [74-76]. Similarly, our laboratory has obtained promising results from an ongoing investigation into blockade of the $\mathrm{C} 1$ component of the complement in our porcine model. Blocking the innate immune response, particularly the danger

Table 2 Potential unfolded protein response therapeutic targets

\begin{tabular}{lll}
\hline UPR target & Molecule & Reference \\
\hline eIF2 $\alpha$ & Salubrinal & {$[65,66]$} \\
$\begin{array}{l}\text { IRE1 } \alpha \text { 's endoribonuclease } \\
\text { activity }\end{array}$ & $4 \mu 8 \mathrm{c}$, STF083010 & {$[71]$} \\
CHOP & Specific siRNA & {$[68,70]$} \\
Unfolded proteins & Sodium-4- & {$[69]$} \\
GRP78 & phenylbutyrate & {$[67]$} \\
\hline
\end{tabular}

UPR Unfolded protein response. Salubrinal inhibitor of elF2a's dephaspharylation leading to an activation of the PERK-elF2a-ATF4 pathway. $4 \mu 8 c$, STF0 83010 inhibitor of IRE1a's endoribonuclease activity avoiding XBP1 mRNA splicing and the regulated IRE1a-dependen decay (RIDD). Sodium-4-pheunylbutyrate A chemical chaperone 
Table 3 Clinical trials on kidney ischemia-reperfusion injury

\begin{tabular}{|c|c|c|c|c|c|c|c|}
\hline Therapeutic strategy & Target & Function & Results & Status & $\begin{array}{l}\text { Clinical trial } \\
\text { ID }\end{array}$ & Last update & Reference \\
\hline Pharmacological & $\mathrm{HO}-1$ & Cytoprotection & $\mathrm{x}$ & Phase 3-Ongoing & NCT01430156 & June 2013 & $\mathrm{x}$ \\
\hline Pharmacological & $\mathrm{TNF} \alpha$ & Inflammation & $\mathrm{x}$ & $\begin{array}{l}\text { Phase 2- } \\
\text { Recruiting }\end{array}$ & NCT01731457 & $\begin{array}{l}\text { November } \\
2012\end{array}$ & $\mathrm{x}$ \\
\hline Pharmacological & HMG-CoA & Cytprotection & $\mathrm{x}$ & $\begin{array}{l}\text { Phase } 0 \text { - } \\
\quad \text { Recruiting }\end{array}$ & NCT01160978 & May 2013 & $\mathrm{x}$ \\
\hline Pharmacological & EPO & Cytprotection & $\begin{array}{l}\text { No effect on long-term graft } \\
\text { function or histology }\end{array}$ & $\begin{array}{l}\text { Phase } 3 \text { - } \\
\quad \text { Completed }\end{array}$ & NCT00425698 & $\begin{array}{l}\text { September } \\
2010\end{array}$ & {$[74]$} \\
\hline Pharmacological & $\begin{array}{l}\text { P-, E-, L- } \\
\text { selectins }\end{array}$ & $\begin{array}{l}\text { Innate } \\
\text { immunity }\end{array}$ & $\begin{array}{l}\text { No impact on the dialysis- } \\
\text { DGF rate. }\end{array}$ & $\begin{array}{l}\text { Phase } 1 / 2- \\
\text { Completed }\end{array}$ & NCT00298181 & January 2008 & {$[75]$} \\
\hline Pharmacological & Annexin 5 & Cytoprotection & Serious adverse effects. & $\begin{array}{l}\text { Phase } 2 / 3- \\
\text { Terminated }\end{array}$ & NCT01442337 & $\begin{array}{l}\text { September } \\
2013\end{array}$ & $\mathrm{x}$ \\
\hline Pharmacological & tPA & Coagulation & $\mathrm{x}$ & $\begin{array}{l}\text { Unknown- } \\
\text { Recruiting }\end{array}$ & NCT01197573 & $\begin{array}{l}\text { February } \\
2013\end{array}$ & $\mathrm{x}$ \\
\hline Pharmacological & HGF & Cytoprotection & $\mathrm{x}$ & $\begin{array}{l}\text { Phase 2- } \\
\text { Recruiting }\end{array}$ & NCT01286727 & May 2013 & $\mathrm{x}$ \\
\hline Pharmacological & EPO & Cytoprotection & $\begin{array}{l}\text { No benefits at the reperfusion } \\
\text { phase on DGF or short- } \\
\text { term } \\
\text { allograft function. }\end{array}$ & $\begin{array}{l}\text { Phase } 4- \\
\text { Completed }\end{array}$ & NCT00425126 & May 2010 & {$[76]$} \\
\hline $\begin{array}{l}\text { Pharmacological } \\
\text { (siRNA) }\end{array}$ & $\mathrm{p} 53$ & Cytoprotection & $\mathrm{x}$ & $\begin{array}{c}\text { Phase } 1 / 2- \\
\text { Ongoing }\end{array}$ & NCT00802347 & June 2013 & $\mathrm{x}$ \\
\hline Pharmacological & $\begin{array}{l}\text { C5 } \\
\text { component }\end{array}$ & $\begin{array}{l}\text { Innate } \\
\text { immunity }\end{array}$ & $\mathrm{x}$ & $\begin{array}{l}\text { Phase 2- } \\
\quad \text { Recruiting }\end{array}$ & NCT01403389 & January 2013 & $\mathrm{x}$ \\
\hline Pharmacological & TLR2 & $\begin{array}{l}\text { Innate } \\
\text { immunity }\end{array}$ & $\mathrm{x}$ & $\begin{array}{l}\text { Phase 2- } \\
\text { Recruiting }\end{array}$ & NCT01794663 & $\begin{array}{c}\text { October } \\
2013\end{array}$ & $\mathrm{x}$ \\
\hline
\end{tabular}

$D G F$ Delayed graft function, HO-1 Heme Oxygenase 1. TNFa Tumor Necrosis Factor a. HMG-CoA 3-hydroxy-3-methylglutarylcoemzyme A. EPO Erythropoietin. $t P A$ tissue Plasminogen Activitor. $H G F$ hepatocyte Growth Factor. TLR2 Toll Like Receptor 2

signal HMGB1 or one of its receptors (TLR2 and TLR4), also represents an interesting strategy. A clinical trial assessing the benefits of TLR2 blockade by the humanized anti-TLR antibody OPN-305 [77, 78] is ongoing (Table 3). Studies on ischemia-reperfusion have not yet identified a unique therapeutic target that reduces its lesions-rather they have highlighted several key factors, each affecting different cell functions (Table 3), which is concordant with the complexity of the ischemia-reperfusion syndrome. A pivotal question arises: is there a single treatment? Our feeling is that the modulation of ischemia-reperfusion injury has to combine different approaches and that, ultimately, the most important aim should be to identify priority targets and develop research programs to clarify this aspect.

\section{Strategies to optimize kidney recovery: the role of mesenchymal stem cell- and progenitor cell-based therapy in pediatric recipients}

In the case of the pediatric recipient, post-transplant lymphoproliferative disease remains a complication of solid organ transplantation and its incidence within the first 5 years following kidney transplantation is approximately $1-2 \%$, while it reaches $20 \%$ in lung or intestine transplantation [79]. Association between post-transplant lymphoproliferative disease and immunosuppressive drugs is unquestioned, even if the exact contribution of each immunosuppressive agent in this lymphoproliferative disease development after solid organ transplantation is not clear. Another major concern about immunosuppressant treatment following kidney transplantation is the high rate of treatment non-adherence, which is $>30 \%$ in pediatric recipients. A systematic review on pediatric kidney transplant patients published in 2010 suggests that about $44 \%$ of all graft losses and $23 \%$ of late acute rejection episodes are associated with non-adherence to immunosuppressant therapy [80].

In this context, long-term allograft survival with a reduction or withdrawal of immunosuppression is of great interest. Although spontaneous immune tolerance in recipients in the case of kidney transplant is rare [81], immune tolerance to allografts can be achieved by three main mechanisms: clonal deletion, anergia and immune regulation. Hematopoietic stem cells were the first cell type assessed in patients for the induction of chimerism and subsequent allograft tolerance [82], but this approach is associated with graft versus host 


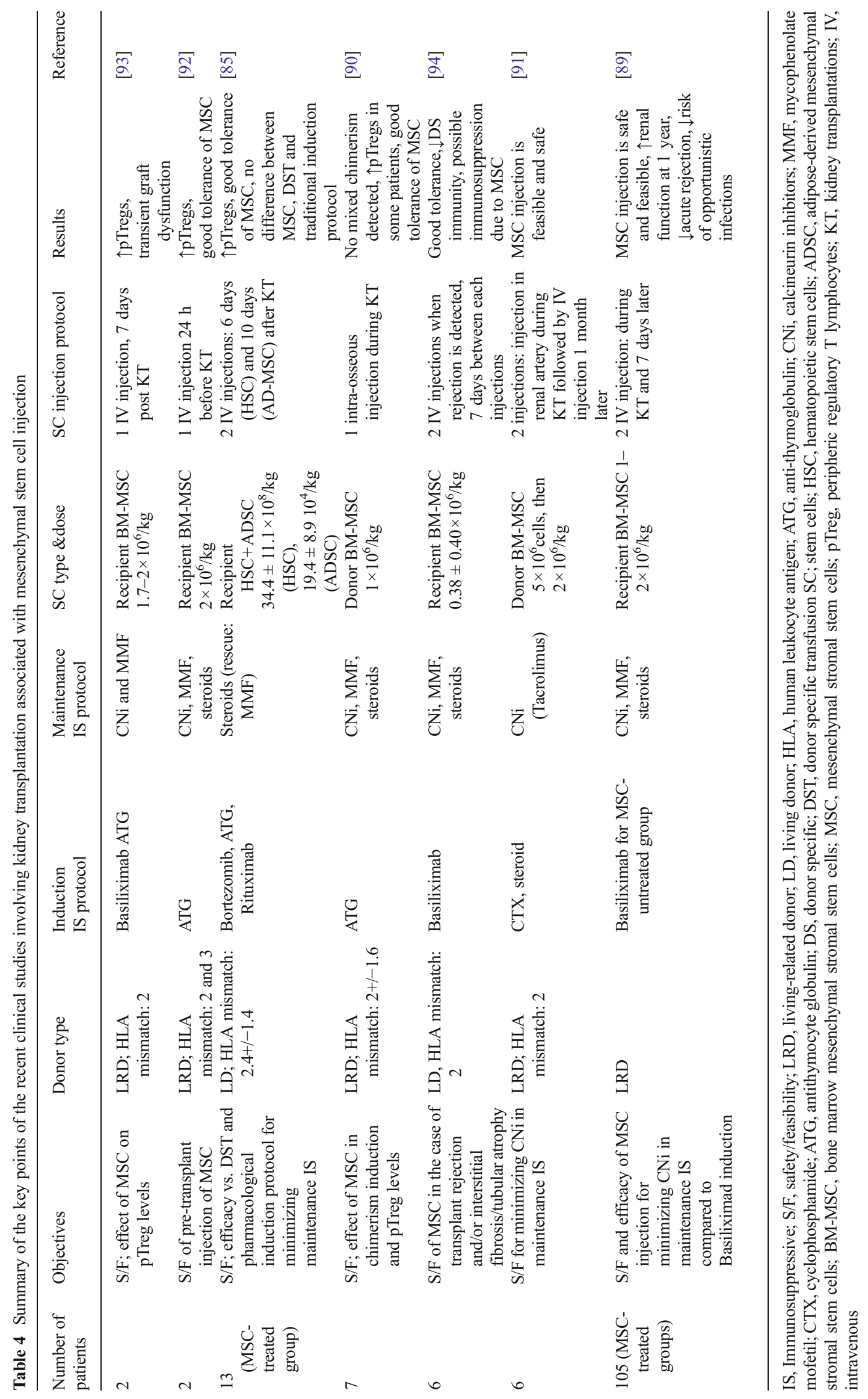


disease (GVHD), humoral rejection and graft loss in some cases [83]. Recent studies have shown that the injection of "facilitating cells" [84] or mesenchymal stem cells $[85,86]$ in combination with hematopoietic stem cells could protect recipients from GVHD and allow the long-term induction of chimerism and tolerance. Given their immunomodulatory properties [87], mesenchymal stem cells are a promising tool to induce allograft-specific tolerance and potentially the subsequent withdrawal of immunosuppressive therapy. In the context of active inflammation, these stem cells can secrete soluble factors and induce pro-inflammatory cell anergy and apoptosis through the stimulation of regulatory $\mathrm{T}$ cells and tolerogenic dendritic cells [87]. The ability of mesenchymal stem cells to modulate both innate and adaptive responses can be crucial in the case of sterile inflammation (inflammation in the absence of microorganisms), as encountered during allograft immune rejection [88].

Injections of mesenchymal stem cells have been tested in recent clinical trials for the treatment of patients undergoing kidney transplantation (Table 4). These studies are mainly feasibility and safety studies on adult recipients from LD. Only one study has been performed to assess the efficacy of these stem cell injections [89] compared to anti-interleukin-2 receptor antibodies. The authors of this study concluded that autologous mesenchymal stem cell injection results in a lower incidence of acute rejection, a decreased risk of opportunistic infection and better regulated renal function at 1 year. Thus, although these studies differ in many aspects, such as the type of mesenchymal stem cells, their allogeneic or autologous status, their time and site of injection and protocols of immunosuppressive therapy, all of them suggest that stem cell injection is a safe strategy [90-94]. However, these studies were performed in LD kidneys, and not in those obtained through DBD or DCD, which are more sensitive to ischemia-reperfusion sequence. Thus there is a need for mesenchymal stem cell injection assessment in these cases of higher exposure to deleterious sterile inflammation [14]. Moreover, this kind of therapy is recent, and it is far too early to say if mesenchymal stem cell injection could become a usual support treatment for kidney transplantation in the future. Indeed, efforts should be made to precisely define the protocols of injection, especially in terms of method of administration (intra-venous, intra-osseous, intra-renal), timing of injections (before kidney transplantation, during conservation, reperfusion, after kidney transplantation), immune status of the cells (allogenic or autologous), their tissue of origin and their dose.

More precisely, in the case of pediatric recipients of a kidney transplant the use of third-party mesenchymal stem cells coming from bio-banks could be helpful. Although allogenic stem cell banking is at the developmental stage [95], especially in the case of induced pluripotent stem cells [96], studies assessing the injection of third-part mesenchymal stem cells associated with solid organ transplantation are needed.

A last promising strategy involving local renal progenitor/ stem cell recruitment and/or activation must be mentioned. These cells have recently been identified as resident cells responsible for kidney tissue regeneration following injury. In vitro cultures of these renal progenitor/stem cells have provided new insight into regeneration mechanisms in the kidney [97]. It could be therapeutically valuable to trigger the cellular pathways activating or recruiting such cells to induce regeneration of renal transplants $[98,99]$.

\section{Conclusion}

Kidney transplantation is the primary therapeutic choice for the treatment of ESRD in both adults and children. However, this efficacious treatment is limited by the current shortage in organs. LD are usually used for children, but in some cases DBD or DCD organs are collected. Thus, renal transplantation in children is optimum with good quality organs from LD and
Fig. 1 Proposed therapeutic strategies to optimize graft survival according to the type of donor and the levels of injury. $L D$ Living donor, $D B D$ donation after brain death, $D C D$ donation after cardiac death, $E C D$ expanded criteria donors, $P E G$ polyethylene glycol, $T M Z$ trimetazidine (Vastagref), UPR unfolded protein response

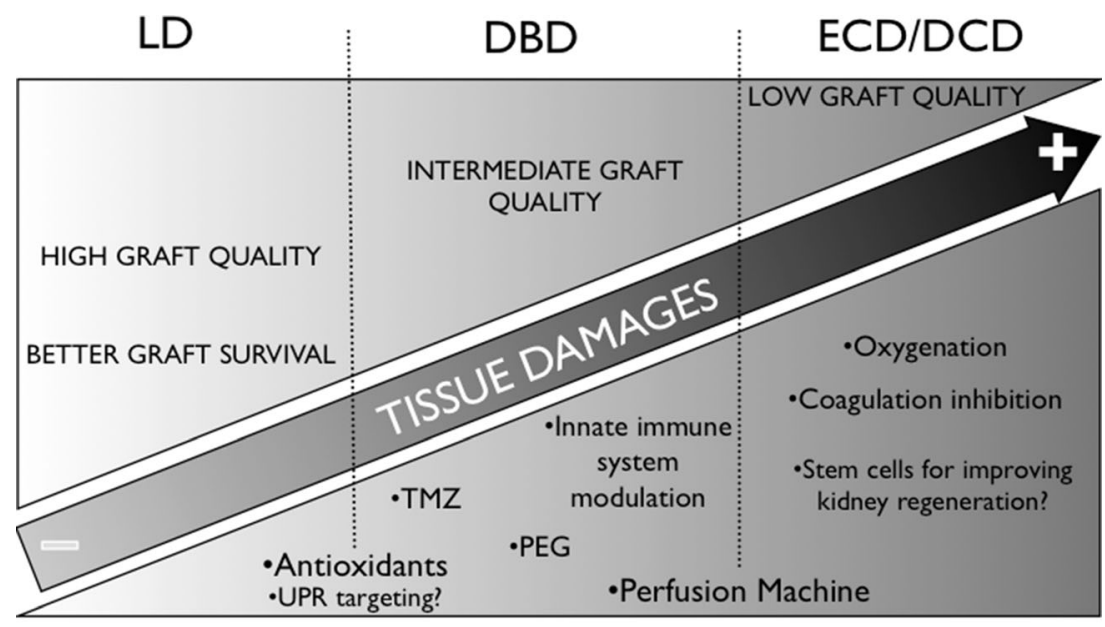

Stem cells for immune tolerance? 
reduced cold ischemia time. Nevertheless, these conditions remain associated with a modulation in the structure and functions of endothelial cells, as well as with endoplasmic reticulum induced-stress activation. In addition, a short conservation period could preserve ATP production in the graft and stimulate beneficial apoptotic pathways rather than necrosis. However, the renal graft is subjected to an unavoidable process of ischemia and subsequent hypoxia, which is more detrimental in deceased donor conditions. Ischemia-reperfusion injury due to the surgical procedure in combination with cold preservation of the organ and transplantation into the recipient is one keystone of graft survival. Hence, it is of paramount importance to pay special attention to several elements that can affect the quality of organ preservation, such as donor hemodynamics, ionic homeostasis and the duration of cold ischemia. The strategies to optimize kidney recovery and preservation in transplantation should be adapted to the donors, particularly in terms of hemodynamics, duration of ischemia and comorbidity factors. Figure 1 presents the levels of damage found in grafts from the different types of donors (LD, DBD, DCD, ECD) and the most efficient therapy for each of these.

\section{Multiple choice questions (answers are provided following the reference list)}

1. Which of the following statements concerning the use of animal models to study kidney graft recovery and preservation is correct?

a) Cellular models are ineffective due to the complexity and the high number of biological processes induced by renal transplantation.

b) Preclinical animal models have shown the importance of preservation solution composition in graft outcome.

c) In rodents, renal transplant surgery requires experienced surgeons and is associated with numerous surgical failures.

d) It is important to look for ways to reduce the number of experimental animals used.

e) The consequences of renal ischemia-reperfusion are also observed in the long-term follow-up of kidney grafts.

f) All of the above.

2. Which of the following assertions is correct?

a) There is no minimum legal age for living donation.

b) Organs from LD, DBD and DCD present the same levels of tissue damage.

c) The "Share 35" program aims to decrease the donors' age for pediatric recipients. d) In the USA, cerebral blood flow measurement is required for diagnosis of brain death in children.

e) The composition of static storage preservation solutions has no direct influence on graft survival.

3. Which of the following assertions concerning the endothelium in ischemia-reperfusion injury is incorrect?

a) The first target of ischemia-reperfusion injury is the microvasculature.

b) Autophagy and the unfolded protein response are two interconnected pathways.

c) Adaptive immunity blockade by a humanized antiTLR2 antibody could improve organ protection by activating the danger signaling pathway.

d) The microvasculature can be analyzed by different techniques such as high resolution micro-computed tomography.

e) The additives to preservation solution such as polyethylene glycol could improve graft outcome.

4. Which of the following is not a main mechanism of graft tolerance?

a) Clonal deletion.

b) Anergia.

c) Immunosuppressive treatments.

d) Immune regulation.

5. Which of the following is correct? Clinical trials linking mesenchymal stem cell therapy and kidney transplantation:

a) Are mainly class II trials.

b) Show major adverse effects or safety issues due to stem cell injection.

c) Have been performed mostly on large cohorts of patients.

d) Have never involved pediatric recipients.

e) Have homogeneous protocols of stem cell injection.

Acknowledgments The authors would like to thank the Nature Publishing Group for the opportunity to adapt Table 1 from Bon et al. [30].

\section{References}

1. Harambat J, van Stralen KJ, Kim JJ, Tizard EJ (2012) Epidemiology of chronic kidney disease in children. Pediatr Nephrol 27:363-373

2. European Society for Paediatric Nephrology/European Renal Association-European Dialysis and Transplant Association (2010). ESPN/ERA-EDTA registry annual report Available at: http://www. espn-reg.org/

3. North American Pediatric Renal Trials and Collaborative Studies (NAPRTCS) (2010) NAPRTCS annual transplant report. Available at: https://web.emmes.com/study/ped/annlrept/2010_Report.pdf 
4. van Dijk PC, Jager KJ, de Charro F, Collart F, Cornet R, Dekker FW, Gronhagen-Riska C, Kramar R, Leivestad T, Simpson K, Briggs JD (2001) Renal replacement therapy in Europe: the results of a collaborative effort by the ERA-EDTA registry and six national or regional registries. Nephrol Dial Transplant 16:1120-1129

5. van der Heijden BJ, van Dijk PC, Verrier-Jones K, Jager KJ, Briggs JD (2004) Renal replacement therapy in children: data from 12 registries in Europe. Pediatr Nephrol 19:213-221

6. Webb NJ, Johnson R, Postlethwaite RJ (2003) Renal transplantation. Arch Dis Child 88:844-847

7. Kobayashi E, Hishikawa S, Teratani T, Lefor AT (2012) The pig as a model for translational research: overview of porcine animal models at Jichi Medical University. Transplant Res 1:8

8. Favreau F, Giraud S, Bon D, Chatauret N, Thuillier R, Hauet T (2013) Ischemia reperfusion control: the key of kidney graft outcome. Med Sci (Paris) 29:183-188

9. Giraud S, Favreau F, Chatauret N, Thuillier R, Maiga S, Hauet T (2011) Contribution of large pig for renal ischemia-reperfusion and transplantation studies: the preclinical model. J Biomed Biotechnol 2011:532127

10. Simmons MN, Schreiber MJ, Gill IS (2008) Surgical renal ischemia: a contemporary overview. J Urol 180:19-30

11. Lerman LO, Schwartz RS, Grande JP, Sheedy PF, Romero JC (1999) Noninvasive evaluation of a novel swine model of renal artery stenosis. J Am Soc Nephrol 10:1455-1465

12. Rothkotter HJ (2009) Anatomical particularities of the porcine immune system-a physician's view. Dev Comp Immunol 33:267-272

13. Thuillier R, Renard C, Rogel-Gaillard C, Demars J, Milan D, Forestier L, Ouldmoulene A, Goujon JM, Badet L, Hauet T (2011) Effect of polyethylene glycol-based preservation solutions on graft injury in experimental kidney transplantation. Br J Surg 98:368-378

14. Rossard L, Favreau F, Giraud S, Thuillier R, Le Pape S, Goujon JM, Valagier A, Hauet T (2013) Role of warm ischemia on innate and adaptive responses in a preclinical renal auto-transplanted porcine model. J Transl Med 11:129

15. Baulier E, Favreau F, Le Corf A, Jayle C, Schneider F, Goujon JM, Feraud O, Bennaceur-Griscelli A, Hauet T, Turhan AG (2014) Amniotic fluid-derived mesenchymal stem cells prevent fibrosis and preserve renal function in a preclinical porcine model of kidney transplantation. Stem Cells Transl Med 3:809-820

16. Matas AJ, Smith JM, Skeans MA, Thompson B, Gustafson SK, Schnitzler MA, Stewart DE, Cherikh WS, Wainright JL, Snyder JJ, Israni AK, Kasiske BL (2014) OPTN/SRTR 2012 annual data report: kidney. Am J Transplant 14[Suppl 1]:11-44

17. Gordon EJ (2012) Informed consent for living donation: a review of key empirical studies, ethical challenges and future research. Am J Transplant 12:2273-2280

18. Gulati A, Sarwal MM (2010) Pediatric renal transplantation: an overview and update. Curr Opin Pediatr 22:189-196

19. Campbell M, Wright L, Greenberg RA, Grant D (2013) How young is too young to be a living donor? Am J Transplant 13:1643-1649

20. Ashwal S, Serna-Fonseca T (2006) Brain death in infants and children. Crit Care Nurse 26:117-124, 126-118

21. Nakagawa TA, Ashwal S, Mathur M, Mysore M (2011) Clinical report-Guidelines for the determination of brain death in infants and children: an update of the 1987 task force recommendations. Pediatrics 128:e720-e740

22. de Vries DK, Wijermars LG, Reinders ME, Lindeman JH, Schaapherder AF (2013) Donor pre-treatment in clinical kidney transplantation: a critical appraisal. Clin Transplant 27:799-808

23. Finfer S, Bohn D, Colpitts D, Cox P, Fleming F, Barker G (1996) Intensive care management of paediatric organ donors and its effect on post-transplant organ function. Intensive Care Med 22:1424-1432

24. Cittanova ML, Leblanc I, Legendre C, Mouquet C, Riou B, Coriat P (1996) Effect of hydroxyethylstarch in brain-dead kidney donors on renal function in kidney-transplant recipients. Lancet 348:1620 $1622 \mathrm{x}$

25. Zuppa AF, Nadkarni V, Davis L, Adamson PC, Helfaer MA, Elliott MR, Abrams J, Durbin D (2004) The effect of a thyroid hormone infusion on vasopressor support in critically ill children with cessation of neurologic function. Crit Care Med 32:2318-2322

26. Schnuelle P, Gottmann U, Hoeger S, Boesebeck D, Lauchart W, Weiss C, Fischereder M, Jauch KW, Heemann U, Zeier M, Hugo C, Pisarski P, Kramer BK, Lopau K, Rahmel A, Benck U, Birck R, Yard BA (2009) Effects of donor pretreatment with dopamine on graft function after kidney transplantation: a randomized controlled trial. JAMA 302:1067-1075

27. Dagher NN, Lonze BE, Singer AL, Simpkins CE, Desai NM, Montgomery RA, Segev DL (2011) Outcomes and discard of kidneys from pediatric donors after cardiac death. Transplantation 91: $765-771$

28. Workman JK, Myrick CW, Meyers RL, Bratton SL, Nakagawa TA (2013) Pediatric organ donation and transplantation. Pediatrics 131: e1723-e1730

29. Committee on Hospital Care SoS, Section on Critical C (2010) Policy statement-pediatric organ donation and transplantation. Pediatrics $125: 822-828$

30. Bon D, Chatauret N, Giraud S, Thuillier R, Favreau F, Hauet T (2012) New strategies to optimize kidney recovery and preservation in transplantation. Nat Rev Nephrol 8:339-347

31. Thuillier R, Giraud S, Favreau F, Goujon JM, Desurmont T, Eugene M, Barrou B, Hauet T (2011) Improving long-term outcome in allograft transplantation: role of ionic composition and polyethylene glycol. Transplantation 91:605-614

32. Hauet T, Eugene M (2008) A new approach in organ preservation: potential role of new polymers. Kidney Int 74:998-1003

33. Faure JP, Baumert H, Han Z, Goujon JM, Favreau F, Dutheil D, Petit I, Barriere M, Tallineau C, Tillement JP, Carretier M, Mauco G, Papadopoulos V, Hauet T (2003) Evidence for a protective role of trimetazidine during cold ischemia: targeting inflammation and nephron mass. Biochem Pharmacol 66:2241-2250

34. Thuillier R, Dutheil D, Trieu MT, Mallet V, Allain G, Rousselot M, Denizot M, Goujon JM, Zal F, Hauet T (2011) Supplementation with a new therapeutic oxygen carrier reduces chronic fibrosis and organ dysfunction in kidney static preservation. Am J Transplant 11:18451860

35. Desurmont T, Giraud S, Cau J, Goujon JM, Scepi M, Roumy J, Chatauret N, Thuillier R, Hauet T (2011) Trophic factor and FR167653 supplementation during cold storage rescue chronic renal injury. J Urol 185:1139-1146

36. Neil DAH, Lynch SV, Hardie IR, Effeney DJ (2002) Cold storage preservation and warm ischaemic injury to isolated arterial segments: endothelial cell injury. Am J Transplant 2:400-409

37. Thuillier R, Tillement J, Hauet T (2009) Renal protective effect of metabolic therapy in patients with coronary artery disease and diabetes: from bench to bed side. Curr Pharm Des 15:863-882

38. Kim I, Xu W, Reed JC (2008) Cell death and endoplasmic reticulum stress: disease relevance and therapeutic opportunities. Nat Rev Drug Discov 7:1013-1030

39. Fähling M (2009) Cellular oxygen sensing, signalling and how to survive translational arrest in hypoxia. Acta Physiol 195:205-230

40. Arroyo CM, Kramer JH, Dickens BF, Weglicki WB (1987) Identification of free radicals in myocardial ischemia/reperfusion by spin trapping with nitrone DMPO. FEBS Lett 221:101-104

41. Kokura S, Wolf RE, Yoshikawa T, Granger DN, Aw TY (2000) Tlymphocyte-derived tumor necrosis factor exacerbates anoxiareoxygenation-induced neutrophil-endothelial cell adhesion. Circ Res 86:205-213

42. Segerer S, Cui Y, Hudkins KL, Goodpaster T, Eitner F, Mack M, Schlondorff D, Alpers CE (2000) Expression of the chemokine monocyte chemoattractant protein-1 and its receptor chemokine 
receptor 2 in human crescentic glomerulonephritis. J Am Soc Nephrol 11:2231-2242

43. Vakeva AP, Agah A, Rollins SA, Matis LA, Li L, Stahl GL (1998) Myocardial infarction and apoptosis after myocardial ischemia and reperfusion: role of the terminal complement components and inhibition by anti-C 5 therapy. Circulation 97:2259-2267

44. Paller MS (1992) Free radical-mediated postischemic injury in renal transplantation. Ren Fail 14:257-260

45. Mahfoudh-Boussaid A, Zaouali MA, Hauet T, Hadj-Ayed K, Miled AH, Ghoul-Mazgar S, Saidane-Mosbahi D, Rosello-Catafau J, Ben Abdennebi H (2012) Attenuation of endoplasmic reticulum stress and mitochondrial injury in kidney with ischemic postconditioning application and trimetazidine treatment. J Biomed Sci 19:71

46. Knight SF, Kundu K, Joseph G, Dikalov S, Weiss D, Murthy N, Taylor WR (2012) Folate receptor-targeted antioxidant therapy ameliorates renal ischemia-reperfusion injury. J Am Soc Nephrol 23:793800

47. Jayle C, Favreau F, Zhang K, Doucet C, Goujon JM, Hebrard W, Carretier M, Eugene M, Mauco G, Tillement JP, Hauet T (2007) Comparison of protective effects of trimetazidine against experimental warm ischemia of different durations: early and long-term effects in a pig kidney model. Am J Physiol Renal Physiol 292:F1082F1093

48. Cenatiempo Y, Belgsir EM, Ramnath M, Favreau F, Carretier M, Mauco G, Hauet T (2011) Method for preserving cells, tissues or organs using a solution comprising alkyldiamine-beta-cyclodextrin. Patent WO 2009068798 A1

49. Szwarc I, Garrigue V, Delmas S, Deleuze S, Chong G, Mourad G (2005) Delayed graft function: a frequent but still unsolved problem in renal transplantation. Nephrol Ther 1:325-334

50. Carden DL, Granger DN (2000) Pathophysiology of ischaemia/ reperfusion injury. J Pathol 190:255-266

51. Zhang M, Alicot EM, Chiu I, Li J, Verna N, Vorup-Jensen T, Kessler B, Shimaoka M, Chan R, Friend D, Mahmood U, Weissleder R, Moore FD, Carroll MC (2006) Identification of the target selfantigens in reperfusion injury. J Exp Med 203:141-152

52. Jang HR, Rabb H (2009) The innate immune response in ischemic acute kidney injury. Clin Immunol 130:41-50

53. Sutton TA, Mang HE, Campos SB, Sandoval RM, Yoder MC, Molitoris BA (2003) Injury of the renal microvascular endothelium alters barrier function after ischemia. Am J Physiol Renal Physiol 285:F191-F198

54. Brodsky SV, Yamamoto T, Tada T, Kim B, Chen J, Kajiya F, Goligorsky MS (2002) Endothelial dysfunction in ischemic acute renal failure: rescue by transplanted endothelial cells. Am J Physiol Renal Physiol 282:F1140-F1149

55. Molitoris BA, Sandoval R, Sutton TA (2002) Endothelial injury and dysfunction in ischemic acute renal failure. Crit Care Med 30:S235S240

56. Eltzschig HK, Eckle T (2011) Ischemia and reperfusion-from mechanism to translation. Nat Med 17:1391-1401

57. Reffelmann T, Hale SL, Dow JS, Kloner RA (2003) Noreflow phenomenon persists long-term after ischemia/ reperfusion in the rat and predicts infarct expansion. Circulation 108:2911-2917

58. Denton KM, Anderson WP, Sinniah R (2000) Effects of angiotensin II on regional afferent and efferent arteriole dimensions and the glomerular pole. Am J Physiol Regul Integr Comp Physiol 279: R629-R638

59. Levinthal C, Ware R (1972) Three dimensional reconstruction from serial sections. Nature 236:207-210

60. Clark RL, Mandel SR, Webster WP (1977) Microvascular changes in canine renal allograft rejection: a correlative microangiographic and histologic study. Invest Radiol 12:62-73
61. Menger MD, Vollmar B (2000) Role of microcirculation in transplantation. Microcirculation 7:291-306

62. Youle RJ, Bliek AM (2012) Mitochondrial fission, fusion, and stress. Science 337:1062-1065

63. Ron D, Walter P (2007) Signal integration in the endoplasmic reticulum unfolded protein response. Nat Rev Mol Cell Biol 8:519-529

64. Haynes CM, Ron D (2010) The mitochondrial UPR - protecting organelle protein homeostasis. J Cell Sci 123:3849-3855

65. Zhu Y, Fenik P, Zhan G, Sanfillipo-Cohn B, Naidoo N, Veasey SC (2008) Eif-2a protects brainstem motoneurons in a murine model of sleep apnea. J Neurosci 28:2168-2178

66. Liu CL, Li X, Hu GL, Li RJ, He YY, Zhong W, Li S, He KL, Wang LL (2012) Salubrinal protects against tunicamycin and hypoxia induced cardiomyocyte apoptosis via the PERK-eIF2alpha signaling pathway. J Geriatr Cardiol 9:258-268

67. Fu HY, Minamino T, Tsukamoto O, Sawada T, Asai M, Kato H, Asano Y, Fujita M, Takashima S, Hori M, Kitakaze M (2008) Overexpression of endoplasmic reticulum-resident chaperone attenuates cardiomyocyte death induced by proteasome inhibition. Cardiovasc Res 79:600-610

68. Han J, Back SH, Hur J, Lin YH, Gildersleeve R, Shan J, Yuan CL, Krokowski D, Wang S, Hatzoglou M, Kilberg MS, Sartor MA, Kaufman RJ (2013) ER-stress-induced transcriptional regulation increases protein synthesis leading to cell death. Nat Cell Biol 15:481490

69. Vilatoba M, Eckstein C, Bilbao G, Smyth CA, Jenkins S, Thompson JA, Eckhoff DE, Contreras JL (2005) Sodium 4-phenylbutyrate protects against liver ischemia reperfusion injury by inhibition of endoplasmic reticulum-stress mediated apoptosis. Surgery 138:342351

70. Yang JR, Yao FH, Zhang JG, Ji ZY, Li KL, Zhan J, Tong YN, Lin LR, He YN (2014) Ischemia-reperfusion induces renal tubule pyroptosis via the CHOP-caspase-11 pathway. Am J Physiol Renal Physiol 306: F75-F84

71. Zeng L, Zampetaki A, Margariti A, Pepe AE, Alam S, Martin D, Xiao Q, Wang W, Jin ZG, Cockerill G, Mori K, Li YS, Hu Y, Chien S, Xu Q (2009) Sustained activation of XBP1 splicing leads to endothelial apoptosis and atherosclerosis development in response to disturbed flow. Proc Natl Acad Sci USA 106:8326-8331

72. Jennewein C, Paulus P, Zacharowski K (2011) Linking inflammation and coagulation: novel drug targets to treat organ ischemia. Curr Opin Anaesthesiol 24:375-380

73. Favreau F, Thuillier R, Cau J, Milin S, Manguy E, Mauco G, Zhu X, Lerman LO, Hauet T (2010) Anti-thrombin therapy during warm ischemia and cold preservation prevents chronic kidney graft fibrosis in a DCD model. Am J Transplant 10:30-39

74. Hafer C, Becker T, Kielstein JT, Bahlmann E, Schwarz A, Grinzoff N, Drzymala D, Bonnard I, Richter N, Lehner F, Klempnauer J, Haller H, Traeder J, Fliser D (2011) High-dose erythropoietin has no effect on short- or long-term graft function following deceased donor kidney transplantation. Kidney Int 81:314-320

75. Osama Gaber A, Mulgaonkar S, Kahan BD, Steve Woodle E, Alloway R, Bajjoka I, Jensik S, Klintmalm GB, Patton PR, Wiseman A, Lipshutz G, Kupiec-Weglinski J, Gaber LW, Katz E, Irish W, Squiers EC, Hemmerich S (2011) YSPSL (rPSGL-Ig) for improvement of early renal allograft function: a double-blind, placebo-controlled, multi-center Phase IIa study1,2,3: $\mathrm{Ph} 2 \mathrm{a}$ trial of rPSGL-Ig in renal transplant. Clin Transplant 25:523-533

76. Sureshkumar KK, Hussain SM, Ko TY, Thai NL, Marcus RJ (2012) Effect of high-dose erythropoietin on graft function after kidney transplantation: a randomized, double-blind clinical trial. Clin J Am Soc Nephrol 7:1498-1506

77. Wu H, Ma J, Wang P, Corpuz TM, Panchapakesan U, Wyburn KR, Chadban SJ (2010) HMGB1 contributes to kidney ischemia reperfusion injury. J Am Soc Nephrol 21:1878-1890 
78. Pulskens WP, Teske GJ, Butter LM, Roelofs JJ, van der Poll T, Florquin S, Leemans JC (2008) Toll-like receptor-4 coordinates the innate immune response of the kidney to renal ischemia/ reperfusion injury. PLoS One 3:e3586

79. Mynarek M, Hussein K, Kreipe HH, Maecker-Kolhoff B (2013) Malignancies after pediatric kidney transplantation: more than PTLD? Pediatr Nephrol. doi:10.1007/s00467-013-2622-5

80. Dobbels F, Ruppar T, De Geest S, Decorte A, Van DammeLombaerts R, Fine RN (2010) Adherence to the immunosuppressive regimen in pediatric kidney transplant recipients: a systematic review. Pediatr Transplant 14:603-613

81. Newell KA, Asare A, Kirk AD, Gisler TD, Bourcier K, Suthanthiran M, Burlingham WJ, Marks WH, Sanz I, Lechler RI, HernandezFuentes MP, Turka LA, Seyfert-Margolis VL, Immune Tolerance Network ST507 Study Group (2010) Identification of a B cell signature associated with renal transplant tolerance in humans. J Clin Invest 120:1836-1847

82. Kawai T, Cosimi AB, Spitzer TR, Tolkoff-Rubin N, Suthanthiran M, Saidman SL, Shaffer J, Preffer FI, Ding R, Sharma V, Fishman JA, Dey B, Ko DS, Hertl M, Goes NB, Wong W, Williams WW Jr, Colvin RB, Sykes M, Sachs DH (2008) HLA-mismatched renal transplantation without maintenance immunosuppression. N Engl J Med 358:353-361

83. Scandling JD, Busque S, Dejbakhsh-Jones S, Benike C, Sarwal M, Millan MT, Shizuru JA, Lowsky R, Engleman EG, Strober S (2012) Tolerance and withdrawal of immunosuppressive drugs in patients given kidney and hematopoietic cell transplants. Am J Transplant 12:1133-1145

84. Leventhal J, Abecassis M, Miller J, Gallon L, Ravindra K, Tollerud DJ, King B, Elliott MJ, Herzig G, Herzig R, Ildstad ST (2012) Chimerism and tolerance without GVHD or engraftment syndrome in HLA-mismatched combined kidney and hematopoietic stem cell transplantation. Sci Transl Med 4:124ra128

85. Dave SD, Vanikar A, Trivedi HL, Gumber MR, Patel HV, Shah PR, Kute VB (2013) Stem cells versus donor specific transfusions for tolerance induction in living donor renal transplantation: a singlecenter experience. Transplantation 95:155-160

86. Vanikar AV, Trivedi HL, Feroze A, Kanodia KV, Dave SD, Shah PR (2011) Effect of co-transplantation of mesenchymal stem cells and hematopoietic stem cells as compared to hematopoietic stem cell transplantation alone in renal transplantation to achieve donor hypo-responsiveness. Int Urol Nephrol 43:225-232

87. English K (2013) Mechanisms of mesenchymal stromal cell immunomodulation. Immunol Cell Biol 91:19-26

88. Ingulli E (2010) Mechanism of cellular rejection in transplantation. Pediatr Nephrol 25:61-74

89. Tan J, Wu W, Xu X, Liao L, Zheng F, Messinger S, Sun X, Chen J, Yang S, Cai J, Gao X, Pileggi A, Ricordi C (2012) Induction therapy with autologous mesenchymal stem cells in living-related kidney transplants: a randomized controlled trial. JAMA 307:1169-1177

90. Perico N, Casiraghi F, Introna M, Gotti E, Todeschini M, Cavinato RA, Capelli C, Rambaldi A, Cassis P, Rizzo P, Cortinovis M, Marasa M, Golay J, Noris M, Remuzzi G (2011) Autologous mesenchymal stromal cells and kidney transplantation: a pilot study of safety and clinical feasibility. Clin J Am Soc Nephrol 6:412-422

91. Lee H, Park JB, Lee S, Baek S, Kim H, Kim SJ (2013) Intra-osseous injection of donor mesenchymal stem cell (MSC) into the bone marrow in living donor kidney transplantation; a pilot study. J Transl Med 11:96

92. Perico N, Casiraghi F, Gotti E, Introna M, Todeschini M, Cavinato RA, Capelli C, Rambaldi A, Cassis P, Rizzo P, Cortinovis M, Noris M, Remuzzi G (2013) Mesenchymal stromal cells and kidney transplantation: pretransplant infusion protects from graft dysfunction while fostering immunoregulation. Transpl Int 26:867-878

93. Reinders ME, de Fijter JW, Roelofs H, Bajema IM, de Vries DK, Schaapherder AF, Claas FH, van Miert PP, Roelen DL, van Kooten C, Fibbe WE, Rabelink TJ (2013) Autologous bone marrow-derived mesenchymal stromal cells for the treatment of allograft rejection after renal transplantation: results of a phase I study. Stem Cells Transl Med 2:107-111

94. Peng Y, Ke M, Xu L, Liu L, Chen X, Xia W, Li X, Chen Z, Ma J, Liao D, Li G, Fang J, Pan G, Xiang AP (2013) Donor-derived mesenchymal stem cells combined with low-dose tacrolimus prevent acute rejection after renal transplantation: a clinical pilot study. Transplantation 95:161-168

95. Thirumala S, Goebel WS, Woods EJ (2013) Manufacturing and banking of mesenchymal stem cells. Expert Opin Biol Ther 13: 673-691

96. Turner M, Leslie S, Martin NG, Peschanski M, Rao M, Taylor CJ, Trounson A, Turner D, Yamanaka S, Wilmut I (2013) Toward the development of a global induced pluripotent stem cell library. Cell Stem Cell 13:382-384

97. Angelotti ML, Ronconi E, Ballerini L, Peired A, Mazzinghi B, Sagrinati C, Parente E, Gacci M, Carini M, Rotondi M, Fogo AB, Lazzeri E, Lasagni L, Romagnani P (2012) Characterization of renal progenitors committed toward tubular lineage and their regenerative potential in renal tubular injury. Stem Cells 30:1714-1725

98. Sallustio F, De Benedictis L, Castellano G, Zaza G, Loverre A, Costantino V, Grandaliano G, Schena FP (2010) TLR2 plays a role in the activation of human resident renal stem/progenitor cells. FASEB J 24:514-525

99. Romagnani P, Anders HJ (2013) What can tubular progenitor cultures teach us about kidney regeneration? Kidney Int 83: $351-353$

\section{Answers}

$1: f$

2:c

2: a) No. Although there is no minimum age limit in England, Wales and North Ireland, underaged living donation is forbidden in some European countries, including France.

2: b)No. Organs from dead donors and particularly DCD present higher tissue damage than LD.

2: d) No. Cerebral blood flow measurement as well as electroencephalography are not required but can be used if clinical examination cannot be completed initially.

2: e) No. The composition of static storage preservation solutions does directly influence graft survival.

3:c (Anti-TLR2 antibody blocks the innate immune system by blocking the danger signal pathway.)

4:c (Actually, graft tolerance is defined by graft survival in the absence of any immunosuppressive treatment, although tolerance can be achieved after immunosuppressive treatment.)

$5: \mathrm{d}$

5: a) No, mainly safety and feasibility studies.

$5:$ b) No, most of the studies report no or minor side effects following stem cell injection.

5: c) No, most of these studies were safety studies performed on a small number of patients.

5: e) No, all the studies differ in term of origin of the stem cells, their dose, route or timing of injection and/or number of injected cells. 